\title{
Professor Oduntan rated by NRF
}

Every year, the National Research Foundation (NRF), South Africa evaluates and rates researchers who apply to be evaluated and rated as researchers in terms of both the South African and international perspectives. The prestigious rating of an individual is based primarily on the quality of the research output of the past seven years as well as the impact of the applicant's work in his or her field and how this has impacted on adjacent fields. The evaluation is undertaken by national and international peer/reviewers who are requested by the NRF to critically scrutinize the research work of the applicant. Professor Oduntan of the University of Limpopo was C-rated in 2006, indicating that he is rated as an established researcher with a sustained recent record of productivity and is recognized by his peers as having produced a body of quality research work. He becomes the third researcher in Optometry to be rated, following Professor Bill Harris and Professor Alan Rubin, both of the University of Johannesburg, who had previously been rated as leading international researcher and established researcher respectively.

Professor Oduntan studied optometry at the University of Benin, Nigeria, becoming the first student to graduate with first class honours degree in Optometry. He graduated in 1982; following one year national service and one year of graduate assistant position in his Department, he left for the UK in October 1984 to pursue post graduate studies. He completed his PhD degree program at the Department of Optometry and Visual Science, The City University, London, UK in 1988. His $\mathrm{PhD}$ project was in ocular anatomy, in which he employed light and electron microscopy, combined with degeneration induced by intracranial neurotomies and superficial nerve

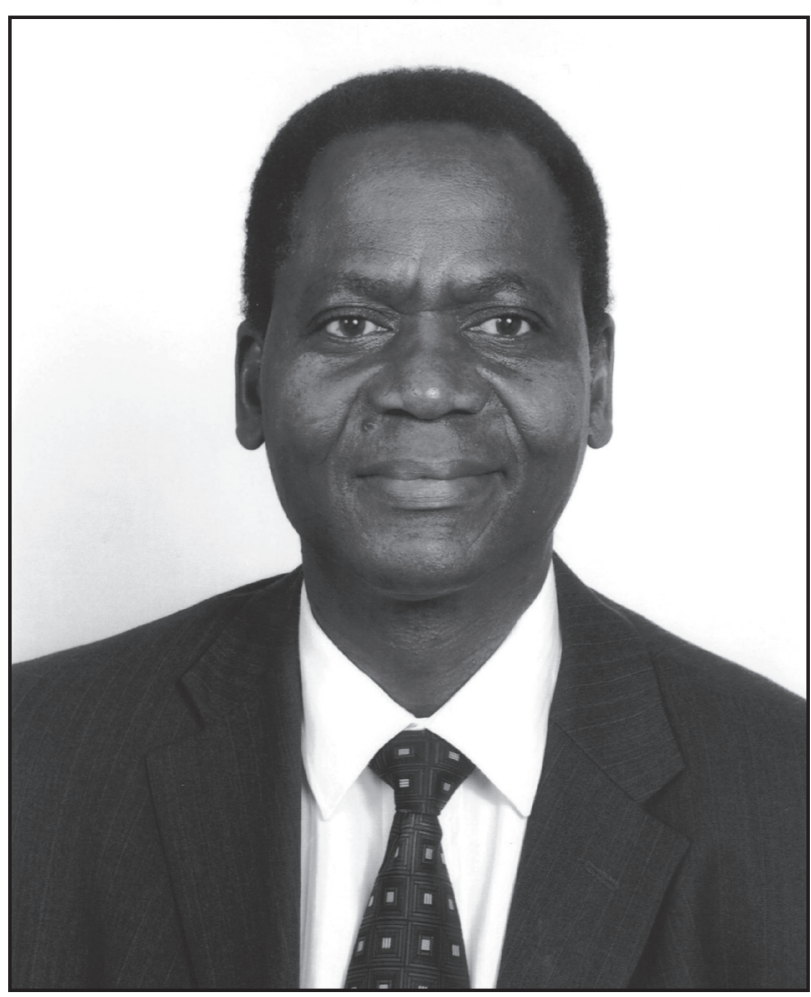

sections to trace the sources of nerve fibres of the lower conjunctiva of monkeys and to study the conjunctival structure and response to denervation. The title of his $\mathrm{PhD}$ thesis is: The primate conjunctiva: Aspects of structure, sensory nerve distribution and response to denervation.

As an undergraduate and post graduate student, he received several scholarship awards including the Commonwealth scholarship with which he studied for the PhD. He was appointed Assistant Professor at the Optometry program, College of Applied medical Sciences, King Saud University, Saudi Arabia in 1989. After 7 years in Saudi Arabia, he moved to South Africa in 1996 as Associate Professor at the Department of Optometry, University of the North (now University of Limpopo, Turfloop campus). He was subsequently appointed full Professor in that University in 2002 . 
Professor Oduntan's academic interests include ocular anatomy, low vision and environmental optometry. He has keen interest in research and has published 52 research articles in several international peer reviewed journals including Acata Anatomica, Clinical and Experimental Optometry, Graefe's Archive for Clinical and Experimental of Ophthalmology, Journal of Anatomy (UK and Ireland), Ophthalmic Research, Ophthalmic and Physiological Optics, Optometry and Vision Science, Saudi Journal of Ophthalmology and South African Optometrist. Although, his initial research works and publications were in ocular anatomy, he has subsequently published in several areas of optometry. Among his major research achievements were: the discovery of an elastic tissue layer in the monkey palpebral conjunctiva ${ }^{1}$ and the establishment that the inferior conjunctiva is innervated mainly by the ophthalmic branch of the trigeminal nerve, contrary to the popular notion that it is innervated mainly or wholly by the inferior branch of the maxillary nerve ${ }^{2}$ (both are part of his $\mathrm{PhD}$ findings) and the documentation of the causes and prevalence of low vision and blindness in black South African adults in the Limpopo Province of South Africa ${ }^{3}$. He has completed a 370 page manuscript for a low vision textbook ${ }^{4}$.

Professor Oduntan has supervised student projects at all levels of optometric education (Undergraduate, Masters and $\mathrm{PhD}$ ) and he has acted as external examiner for Master and $\mathrm{PhD}$ projects. In addition, he has supervised students in Public Health Program. He is currently supervising or co-supervising master students in Optometry, Public Health, Nursing and Psychology. He is a member of the Editorial Board, South African Optometrist and has acted as a reviewer for the National Research Foundation (NRF)'s evaluation centre. He is a member of the Senate research committee of the University of Limpopo.

Professor Oduntan received the JL Saks Literary Award (JL Saks Foundation) in 2000. $\mathrm{He}$ also received Research Excellence Award, 2001, University of the North (Now Univer- sity of Limpopo). He received research assistantship grants from the University of the North/ Limpopo in 1998, 1999, 2006 and 2007. He has attended and presented papers at many local and international conferences. $\mathrm{He}$ is keenly interested in mentoring young researchers.

\section{References}

1. Oduntan AO, Ruskell GL. A sub-epithelial elastic laminar in the palpebral conjunctiva of monkeys. J Anat 1989163 165- 172.

2. Oduntan AO, Ruskell GL. The source of sensory fibres of the inferior conjunctiva of monkeys. Graefe's Arch Ophthalmol $1992230258-263$.

3. Oduntan AO, Nthangeni ME, Ramudzuli MR and Madu SN. Causes and prevalence of low vision and blindness in black South African adults in the Limpopo Province. $S \mathrm{Afr}$ Optom 200362 8-15.

4. Oduntan AO. Contemporary low vision care: A textbook for students and practitioners. 2006. (Unpublished material). 